\begin{tabular}{|c|c|c|c|c|c|c|}
\hline \multirow{4}{*}{ Impact Factor: } & ISRA (India) & $=3.117$ & SIS (USA) & $=0.912$ & ICV (Poland) & $=6.630$ \\
\hline & ISI (Dubai, UAE & $=0.829$ & РИНЦ (Russia) & $=0.156$ & PIF (India) & $=1.940$ \\
\hline & GIF (Australia) & $=0.564$ & ESJI (KZ) & $=8.716$ & IBI (India) & $=4.260$ \\
\hline & JIF & $=1.500$ & SJIF (Morocco) & $=5.667$ & OAJI (USA) & $=0.350$ \\
\hline
\end{tabular}

\section{SOI: $1.1 /$ TAS $\quad$ DOI: $10.15863 /$ TAS \\ International Scientific Journal Theoretical \& Applied Science}

p-ISSN: 2308-4944 (print) e-ISSN: 2409-0085 (online)

Year: 2019 Issue: 07 Volume: 75

Published: $06.07 .2019 \quad \underline{\text { http://T-Science.org }}$
QR - Issue

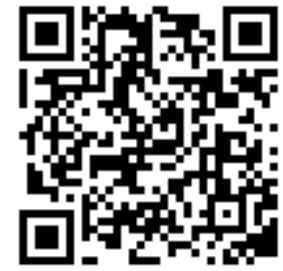

Ramzjon Rakhimjanovich Isakdjanov International islamic academy of Uzbekistan

A senior teacher of Unesco chair in the comparative study of world religions ramzjon.isakdjanov@mail.ru

\title{
THEORETICAL BASES OF STUDYING THE GNOSEOLOGY OF CENTRAL ASIAN PHILOSOPHY
}

Abstract: This article deals with the research of scholars of western Europe, Iran, the former Soviet Union, Russia, Uzbekistan, and the United States, studying the gnoseology of Central Asian scientists and philosophers, and each researcher's method of studying their ideas about Central Asia, particularly Ibn Sino's philosophical heritage and theoretical foundations.

Key words: gnoseology, kalâm, Bayt al-Hikmah, peripateticism, religion philosophy, tafakkur.

Language: English

Citation: Isakdjanov, R. R. (2019). Theoretical bases of studying the gnoseology of central Asian philosophy. ISJ Theoretical \& Applied Science, 07 (75), 22-25.

Soi: http://s-o-i.org/1.1/TAS-07-75-6 Doi: crossef https://dx.doi.org/10.15863/TAS.2019.07.75.6

Classifiers: SECTION 30. Philosophy.

\section{Introduction}

The ideas of the book of Avesto in Zoroastrianism, the views of the Buddhists who had once lived in Termez, and, of course, the ideas of Islamic doctrine and the Greek philosophy of reasoning can be clear examples of the gnoseology of Central Asia. As our research focuses on the X-XI centuries, the philosophical ideology of the Muslim world and its unique ideas are to be represented. In study of this region the researches of scholars from Western, CIS (Commonwealth of Independent States) and Muslim countries are extensive. Of course, the approaches to the study of gnoseology in this region vary, so there are differences between Western and Muslim researchers. While former Soviet philosophers often criticize western schools, their methodology is almost identical to Western methodology. We cannot clearly answer the question of how the school of the Muslim philosophy is, because we do not have a good philosophical school. It is true, the Iranian scholars and Egyptian researchers' works are great. However, as far as the philosophy is concerned, the West comes to mind first. The fact that "philosophy belongs to the West" means that there are still many confusions in this area.
What is our approach here? Gnoseology - learning the philosophers of the Muslim world should include the principles of ontology with the explanation of the Qur'an and its interpretation, the interpretation of the hadith and, of course, the knowledge of Kalâm (a study of the Word). Not only Arabic language and its grammar, but also the ideas of Islamic religion and its spirit will help deepen philosophical interpretation. Only then we will begin to understand the spiritual richness of our ancestors, and this can be the basis for bringing up the future generations with patriotism and a sense of loyalty to the country.

\section{Materials and Methods}

In the study of gnoseology of Central Asian philosophy, the scholars from the CIS countries are the followings: M.S.Asimov, N.Baratov, M.N.Boltaev, A.D.Djakhid, Yu.D.Jumaboev, M.Dinorshoev, A.K.Zakuev, A.X.Qosimjonov, S.K.Satibekova, E.A.Frolova, M.M.Xayrullaev, Stepanyants, A.Sagadeev, G.B.Shaymukhambetova, A.Sharipov and others.

As far as the philosophy of Central Asian gnoseology in X-XI centuries is concerned, Avicenna (Ibn Sino) and Beruni's philosophies can be vivid 


\begin{tabular}{|c|c|c|c|c|c|c|}
\hline \multirow{4}{*}{ Impact Factor: } & ISRA (India) & $=3.117$ & SIS (USA) & $=0.912$ & ICV (Poland) & $=6.630$ \\
\hline & ISI (Dubai, UAE & $=0.829$ & РИНЦ (Russia & $=0.156$ & PIF (India) & $=1.940$ \\
\hline & GIF (Australia) & $=0.564$ & ESJI (KZ) & $=8.716$ & IBI (India) & $=4.260$ \\
\hline & JIF & $=1.500$ & SJIF (Morocco & $=5.667$ & OAJI (USA) & $=0.350$ \\
\hline
\end{tabular}

examples. The Soviet philosophy school of that era attempted to prove these geniuses as materialists and religious critics as possible. One of them, the Oriental scientist A.Sagadeev, argues that medieval Muslim philosophy - peripateticism opposed to the dominant ideology.

Was there any dominant ideology? There are those who take advantage of these ideologies. If the role of the government in Bayt al-Hikmah's construction during the period of Khaleefah Mamun as well as in learning the greek philosophic heritage is considered, the above mentioned idea would be contrary that it is possible to say the dominant ideology has become the embodiment of peripateticism.

$\mathrm{He}$ also notes that in the Middle Ages the Catholic scholars-neotomists more interested in philosophy of Europe. The works of E.Jilson, L.Garde, J.Verbeek, M.Asin, Palasios, R.Arnaldes and A.Korben are clear examples of this.

Sagadeev claims that according to the above mentioned scholars, the basis of Avicenna's doctrine teach the Jewish tradition of the transtcendent concept of God or the types of natural mysticism and intellectual gnosticism, and that Ibn Rushd was considered as the defender of the Holy Koran and fikh (the law of islam) supporting the ideas of peripateticism.

Here the concept of transcendental divinity is a controversial matter to the Judaism and requires a deeper insight into the theories of Avicenna who deeply understood the doctrine of Islam. On the other hand, as talking about the Jewish tradition, Sagadeev pointed that the concept of determining the God came from Vedenta and Judaism to philosophical cosmology at first. In fact, Avicenna who wrote explanations to the Surahs of Holy Koran mentioned that he described the God with his true qualities. With his points he rejected to continue Jewish tradition.

Based on the views of other philosophical historians, Sagadeev who supported the ideology of the Soviet era, researchers from the Commonwealth of Independent States described the success of ArabMuslim philosophy, Avicenna, Ibn Rushd and other Eastern perepatets as an opposing direction to the dominant religious ideology.

In the study of Central Asian philosophy, in particular, Muslim philosophy, it should be mentioned that the ideas of Western researchers who mainly focused on Europe influenced to the main conclusion. The Greek philosophy, which has a great influence on the rational thinking of the Arabs, is perhaps the sum of several viewpoints. Are not the Greeks interested in the ideas of the Iranian people, the doctrine of Zoroastrianism, the views of Vedas and the Buddhism?

The analysis of European ideology in the history of philosophy in Central Asia itself goes to Avesto. Ancient Greco-philosophers such as Solon, Socrates,
Fales, Aristotle, Plato, Heraklit, Democritus, later Western scholars - Anketil du Peron, X.Bartolome, M.Boys, I.M.Steblin-Komensky, J.Kleinz, J.Dyushen-Giemen, X.Humbax, Goethe, Dante, V.B.Hehh analysed the Avesto. Therefore, Avesto influenced greatly to their philosophical views.

In our opinion, he (Alexander Makedonsky) was with his teacher-adviser (Aristotle) in all his occupational battles. Because in Aristotle's views and philosophical doctrines, as many other ancient Greek philosophers, have the influence of Avesto[2,p14-16].

Indeed, Alexander Makedonsky and his teacher Aristotle used this unique heritage of Asia, and the pages translated into Greek were so useful for the people of that period. Plato says: We, ellenes, try to own everything that we have taken from barbarians, and emphasize their priority [3, p-987].

But as Western researchers refer to Oriental philosophers, they point out that they have served as bridges.

In particular, Gegel notes in his book "Religion philosophy" that the main part of the Eastern peripateticism is to comment on the Greek ideological thoughts. He sees the true sense of Oriental thought in mutakallims' pantheism.

Later on, this concept was developed by E.Renan: only mutakallims, that is, the original Arab intellectuals were totally against the Greek philosophy, and believed that the Greek philosophy was determined after the domination of "The Persian spirit" (by Abbasiys) over Arabic. However, a confusion appears, if those who learn the study of Kalâm are called as mutakallims, Abu Hanifa, Moturidi, Abul Hafs Nasafi were Turk or Persian. It is not true to call only Arabs as mutakallims.

French Oriental scholar Anry Corben notes that this philosophy does not belong to "Arab"s but it belongs to "Muslim"s. He also emphasizes that some ideas based on Europe can be found in the study of Muslim gnoseology.

"The evolution and the essence of philosophical thoughts in the Islamic world can only be clear if the views of European philosophy are not considered. Also, the terms of "philosophy" or "philosopher" in Muslim world do not have the same meanings as in real philosophy".

The French researcher A.M.Guashon proves in his fundamental work namely "The difference between existence and availability in Avicenna's doctrine," mentions that the medieval views such as "Avicenna did not differentiate between the essence of things and their existence" are not true.

Ulrikh Rudolph claims: "But when it comes to Moturidhi, there is less risk than the works of other scholars, because his thought is a unique example of learning new theories through various synthesis ways of gnoseology".

Thus, it is the school of devotion which has experienced its conversion in two completely 


\begin{tabular}{|c|c|c|c|c|c|c|}
\hline \multirow{4}{*}{ Impact Factor: } & ISRA (India) & $=3.117$ & SIS (USA) & $=0.912$ & ICV (Poland) & $=6.630$ \\
\hline & ISI (Dubai, UAI & $=0.829$ & РИНЦ (Russia & $=0.156$ & PIF (India) & $=1.940$ \\
\hline & GIF (Australia) & $=0.564$ & ESJI (KZ) & $=8.716$ & IBI (India) & $=4.260$ \\
\hline & JIF & $=1.500$ & SJIF (Morocce & $=5.667$ & OAJI (USA) & $=0.350$ \\
\hline
\end{tabular}

contradictory theories over nine centuries. However, the principles of the philosophy are clearly explained in the book "Kitab as-Savod al-A'zam"; another one was revealed in the works of Abu Karram. The main aspects of his doctrine were kept in Makhul an-Nasafi.

However, the general characteristic of these texts is that the author's religious faith is shown directly. This, in turn, differentiates the whole tradition from the book "Kitab At-Tavhid" that was later seen. There is no mention of only the distinct religious faith with its expression and boundaries. Now it goes about speculative theology. This means that, along with Moturidhi and his work, Movarounnahr entered the history of Kalâm at first.

This difference is more seen in its ways. Moturidhi was not only concerned with emphasizing the doctrines of other scholars with traditional descriptions. He tries to justify the matters that he is talking about with knowing and understanding. Whenever possible, he tries to refer the ideas of some scholars with others'. Any of his predecessors in Mavorounnahr attempted to do this before. He achieved this because of his unique method which was not used by anyone before. He had an epistemology, that is, a theoretical knowledge, with which he analyzed his thoughts and understood various sources of knowledge and then spoke about them [4, p-361].

American researcher Frederick Starr calls IX-X centuries of Central Asia as a "golden age": there were several ways for Central Asia's great scholars achievements in the "golden age". These are deduction, logical argumentation, intuition, experiment, and observation. Moreover, Starr mentioned that Avicenna studied the rational foundations of religion in theology.

Frederick Starr's research style was of a great interest to us. In his words, he gave a high appreciation to Oriental ideology and studied all the facts in detail. But it can be understood that he used "western research" style. For example, as he comments on Beruni and his work "Osor ul-baqiya," some of his views seem to be controversial: Beruni was more interested in identifying the period of the year. As Beruni believes, there are mistakes in the Hijri year, in which he praised the fact that the ancient Egyptians calculated even seconds in detail.

About "Turks who do not like tafakkur", he says: There is a hypothesis that the collapse of the science and philosophical crisis in Central Asia related to the Turks' visit. Accordingly, development in Central Asia is connected with the civilization in the East of Persia. The Turks lived a few centuries before the disappearance of tafakkur. The supporter of these views was the Russian historian Bartold. Maybe this is not about Turks, but about their nomadic actions. Bartold was considered to be against to the nomadic culture of the Turkish people's advanced logic and mathematics [6, p-48].
Some aspects of Islamic philosophy, its formation, the influence of Greek culture, complete human ideas, logical views, especially the views of Avicenna and Ghazali and other compatriots such as M.Khayrullaev, Fayzullaev, M.Abdullaeva, R.Nosirov, M.Kodirov, X.Aliqulov, M.Boltaev, M.Usmonov, A.Sharipov, R.Bahkadirov, A.Zokhidiy, M.Jakbarov, D.Fayzihodzhaeva who partly studied the problems of philosophy help to clearly understand the gnoseology in Islamic philosophy.

After the independence of Uzbekistan, our religious-national values were restored and opportunities were created to study the philosophical views of Islamic philosophers. The contributions of Medieval Uzbek scholars in the study of the Islamic philosophical foundations are great. In this regard, N.Komilov, N.Ibrohimov, Z.Islomov, A.Mansur, A.Hasanov, U.Uvatov, U.Alimov, A.Djuzdjoniy, M.Hasaniy, Z.Munavvarov, Sh.Sirodjiddinov, M.Imomnazarov, S.Akylov and other scholars' contributions are remarkable.

In the East, the studies of Islamic philosophy have improved greatly and are still improving. For example, the Faculty of Islamic Philosophy at the University of Cairo of the Arab Republic of Egypt annually hosts international conferences on various issues of Islamic philosophy and is publishing collections of conference materials. Some of the Egyptian philosophers as Muhammad Sharkavi and Ahmad Arafat al-Kazi made lectures about Islamic gnoseology [7-8, p-93].

Dr. Lutfi Jum'a analyzed the views of Islamic philosophers. Iranian Islamic philosophers are also making important researches. For example, one of the most important researches in Islamic philosophy, the translation of M.Fahri's "History of Islamic Philosophy" was published in Persian by Nasrullo Pur Jawadi in 1983 in Tehran [9, p-320]. Scientific research on Islamic philosophy has also been carried out in the Republic of Turkey. Among them prof. I.Abdulhamid and prof. M.Bayrakdar's monographs play a special role. Sayyid Mohammad Khatami, an Iranian scholar, as he speaks about gnoseology in Central Asia, mentioned three major trends in "The Role of Ideology in the Civilization of Islam".

The ideological and contemporary development of Islamic civilization continued under the influence of three important trends, they can be referred to as "tosharo" (the word shari'a), Sufism and Rationalism [13, p-45].

The glorification of the "second teacher of Islamic philosophy" is that he worked hard and created such a system of tafakkur that only a commentary on his ideas would be required. In any case, why it should be called as "second teacher" is that he used the "philosophy" in various fields of education and in practice created Islamic philosophy" [13, p-69]. 


\begin{tabular}{|c|c|c|c|c|c|c|}
\hline \multirow{4}{*}{ Impact Factor: } & ISRA (India) & $=3.117$ & SIS (USA) & $=0.912$ & ICV (Poland) & $=6.630$ \\
\hline & ISI (Dubai, UAE & $=0.829$ & РИНЦ (Russia & $=0.156$ & PIF (India) & $=1.940$ \\
\hline & GIF (Australia) & $=0.564$ & ESJI (KZ) & $=8.716$ & IBI (India) & $=4.260$ \\
\hline & JIF & $=1.500$ & SJIF (Morocec & $=5.667$ & OAJI (USA) & $=0.350$ \\
\hline
\end{tabular}

Indeed, an Iranian scholar highly appreciates Farabi. It is a great news that he called Farabi as the founder of Islamic philosophy. However, in his work, the study of the history of philosophy seemed as clarifying the political purposes of Shiite rulers.

\section{Conclusion}

Considering above mentioned points we can come to the following conclusion:

1. There are proofs to call our geniuses, Avicenna and Farabi, as the founders of "Islamic philosophy".
2. It has become obvious from the researches that Iranian scholars and Indian researchers' contributions are great in learning Avicenna's theological thoughts and his Tafsir books.

3. As for Avicenna's gnoseology, it would be better to study the Tafsirs of Koran, the hadiths as well as Arabic texts in learning the gnoseology of the Islamic theology.

\section{References:}

1. Sagadeev, A. (n.d.). Oriental peripateticism. Retrieved 2019, from https://pda.liters.ru

2. Khaitov, S. I. (2011). O'zbekiston falsafa tarixi. "Noshir". Tashkent.

3. (n.d.). Plato. "Afterlaw". Retrieved 2019, from https://kitobxon.com

4. Ulrikh, R. (2001). Al-Moturidhi and Samarkandi's Sunni theology. International fund named after Imam al-Bukhari. Tashkent.

5. Starr, S. F. (2017). Lost education: Golden age in Central Asia from arabic occupation till the period of Temurlan. Moscow: Alphin Publisher.

6. Starr, S. F. (2017). Lost education: Golden age in Central Asia during Arabs conquest till the period of Temurlan. Moscow: Alphin Publisher.

7. Sharqavi, M. (1997). Al-falsafat al-islamiyya va takvin al-hiss an. (p.27). Cairo.
8. Arafot, A. (1997). Al-falsafat al-islamiyya va vat-tanvir. // Al-falsafat al-islamiyya va bina alinsan al-ma'asir. Cairo.

9. Dr. Muhammad Lutfi Jum'a (1999). Tarix falosifatil-islam. Maktabatul a'lamil kutub. Cario.

10. Fahri, M. (1983). Sayre falsafa dar eslom. Tehran.

11. Prof. Ifron Abdulhamid (1994). Islomda e'tiqodiy mazhablar va aqoid asoslari. Istanbul: Og'ul matbaasi.

12. Doktor Mehmet Bayrakdar (2003). Islam felsefesiya kirish. Anqara.

13. Hotamiy, S. M. (2003). Islom tafakkuri tarixidan. "Minkhodj”. Toshkent. 